\title{
The Organotin Applications in Biological, Industrial and Agricultural Sectors: A Systematic Review
}

\author{
Abdualbasit M. Graisa ${ }^{1}$, Amani A. Husain ${ }^{2}$, Mohammed H. Al-Mashhadani ${ }^{3}$, Dina S. Ahmed ${ }^{4}$, \\ Hadeel Adil ${ }^{3}$, Emad Yousif ${ }^{3 *}$ \\ ${ }^{1}$ Faculty of Civil Aviation, Ministry of Technical and Technical Education, Misurata, Libya \\ ${ }^{2}$ Polymer Research Unit, College of Science, Al-Mustansiriyah University, Baghdad 10052, Iraq \\ ${ }^{3}$ Department of Chemistry, College of Science, Al-Nahrain University, Baghdad, Iraq \\ ${ }^{4}$ Department of Medical Instrumentation Engineering, Al-Mansour University College, Baghdad, Iraq \\ *Corresponding author: emad_yousif@hotmail.com
}

Received: November 21, 2021

Accepted: December 30, 2021

\begin{abstract}
In the last few decades, the chemistry of organotin (IV) complexes of many biologically important compounds, has received significant interest in the preparation, identification and application of organotin units which are employed as photo-stabilizers, pesticides, pharmaceuticals and fire retardants. Biological properties of the system are modified by changing the organic ligands in organotin(IV) complexes. Using organotin (IV) materials in medications has brought significant attention by researchers recently. This is due to these compounds have demonstrated an excellent biological activity as well as organotin (IV) compounds are considers as anti-oxidant molecules as they work free radical scavengers. On the other hand, organotin (IV) complexes were used as photo-stabilizers for different types of plastic polymers. In this paper will review the most important potential work using organotin (IV) in both medicine and industrial applications.
\end{abstract}

Keywords: organotin, complexes, metal-organic chemistry, biological applications, stabilizer, photodegradation

\begin{abstract}
Abstrak
Dalam beberapa dekade terakhir, senyawa kompleks organotin (IV) dari banyak senyawa penting secara biologis, secara signifikan telah menarik minat banyak pihak. Senyawa organotin digunakan sebagai penstabil foto, pestisida, obat-obatan dan penghambat api. Sifat biologis sistem dimodifikasi dengan mengubah ligan organik dalam kompleks organotin(IV). Penggunaan bahan organotin (IV) dalam pengobatan telah menarik perhatian yang signifikan oleh para peneliti baru-baru ini. Hal ini disebabkan senyawa ini telah menunjukkan aktivitas biologis yang sangat baik serta senyawa organotin (IV) dianggap sebagai molekul anti-oksidan karena bekerja sebagai penangkap radikal bebas. Di sisi lain, kompleks organotin (IV) digunakan sebagai penstabil foto untuk berbagai jenis polimer plastik. Makalah ini akan meninjau pekerjaan potensial yang paling penting menggunakan organotin (IV) baik dalam aplikasi kedokteran maupun industri.
\end{abstract}

Kata kunci: organotin, kompleks, kimia organic metal, aplikasi biologi, penstabil, foto-degradasi

\section{Introduction}

With the development of science and technology to improve the life standards, a lot of new fields have emerged to encounter the emerging and existing challenges to the humankind. A new field, bioorganometallic chemistry has also become popular, interestingly due toits advanced applications in medical research. Bioorganometallic chemistry interfaces with biochemistry and has been recognized as an independent field of research and development. Bioorganometallic chemistry specifically focuses on the incorporation of organometallic fragments into biomolecules where the chemistry of the metal-carbon bond is a central characteristic. Research in bioorganometallic chemistry encompasses a range of studies regarding the study of the role of organometallic materials in biology [1].

Tin chemistry and organotin compounds have a long history of being used to discover profitable uses for tin compounds, dating back to the commencement of the industrial revolution. Organotin compounds were first noticed in the industrial world about 1940, and large-scale synthesis began in the realm of organometallic and coordination chemistry in 1950. These compounds have become an industry, with production rates ranging from 40000 to 51000 tons per year [2, 3]. Tin may form two types of compounds 
in its 4-oxidation state: inorganic and organometallic compounds. Hence it is recognized as a simple area of inorganic and metal-organic chemistry, which has recently gained a lot of importance because of its application in medicine. Different books and review articles $[4,5]$ and [6] on the tin(IV) complexes, and their industrial and pharmacological applications indicating the numerous studies that have been undertaken in the last few decades.

In the last few decades the chemistry of organotin(IV) complexes of many biologically important compounds, has received significant interest $[7,8]$ in many aspects such as organometallic synthesis which are utilized in both industrial and medicine application. Biological properties of the system are modified by changing the organic ligands in organotin(IV) complexes which stimulate the reactivity [9]. Recently Yousif's group has synthesised new di and tri-alkyltin complexes using sulfamethoxazole medication as a ligand as shown in Scheme 1 [10]. They have used the synthesised compounds as phot-stabilizers of PVC.<smiles>Cc1cc(NS(=O)(=O)c2ccc(N)cc2)no1</smiles>

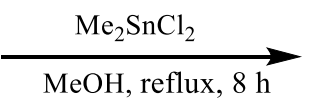<smiles>Cc1cc(NS(=O)(=O)c2ccc(N)cc2)no1</smiles>

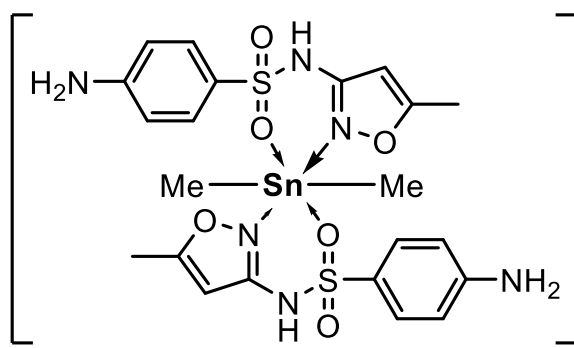
$\mathrm{Cl}_{2}$<smiles></smiles>

\section{$\mathbf{R}=$ ph or $\mathbf{n}-\mathbf{B u}$}

Figure 1. Synthetic rout of Di and tri-organotin(IV) complexes using sulfamethoxazole as a ligand [10].

Organotin compounds' vast variety of uses in chemistry has widened their interactions with other biomolecules, such as carbohydrates, amino acids, and peptides. Ligands that are identified as $(\mathrm{O}, \mathrm{O})$ donors can act in a bidentate way with organotin(IV) compounds to create five- or six-membered chelate rings [11]. The traditional ligand such as hydroxamic acids having two oxygen atoms are still attracting considerable interest because of their biological influence and their potential of being used as a tumour inhibitor [12]. Hydroxamic acids have been well recognized to be a suitable ligand for the organotin compounds. Reports on the biological activity of organotin compounds e.g. antitumour activities illustrate that organotin(IV) compounds $\left(\mathrm{R}_{2} \mathrm{SnX}_{2}\right)$ and their complexes with $\mathrm{Sn}-\mathrm{O}, \mathrm{Sn}-\mathrm{N}$ or $\mathrm{Sn}-\mathrm{S}$ bonds often display biological activity. The technique by which organotin(IV) complexes exert biological action is unclear, and it may differ from one chemical to the other $[9,13]$. However, it has been proposed that the amount of leaving groups available around the $\mathrm{Sn}(\mathrm{IV})$ ion, and hence the form or strength of the complexes' Sn-S and/or Sn-N bonds, impact the biological activity of these molecules. Furthermore, a wide range of biological activities, from fungicidal and insecticidal to antitumor, are found to be a designate feature for some organotin hydroxamic acids [14-16]. Since, hydroxamic acid contains $\mathrm{N}$ and $\mathrm{O}$ atoms therefore they are suitable for formation of organotin complexes that may be biologically active. Previous works on organotin(IV) bishydroxamtes are known to possess a wide range of biologically activity against some types of tumours $[14,15]$.

Synthesis, stability, structure, and reactivity of physiologically active organometallic cationcontaining compounds of low and high molecular weight are all being studied extensively. Interestingly, the study of the role of organometallic cations in metabolism has led to the new discoveries in support of important, naturally occurring compounds and reactions. Biomolecule ligands are particularly versatile, and exhibit permeability to the compounds possessing specific stereochemistry. With the use of organometallic fragments, biomolecular ligands can be synthesized, branded, stabilized, or activated for the purposeful biomedical applications. Organometallic compounds have been recognized well for its curative and remedial applications to enhance the advancement medical practices for a better human life. 
This has an impact on people's quality of life, whether as hazardous contaminants or pharmaceuticals to cure certain diseases [1, 17-19], but the intricacies of their molecular mechanism of action are yet unknown. The current task of contemporary bioorganometallic chemistry is to research the molecular basis of all of these interactions and apply this knowledge to a variety of sectors of science, including health, biology, environmental science, and technology. Scientists from various disciplines are engaged to investigate the functions of organometallic compounds in relation to living systems including application and study of advanced organometallic techniques of biological processes to understand the metabolic processes involved. Examples of the participation of organometallic compounds in biological systems are organotin(IV) compounds [20,21], which are found to be very active as biocidal [22] antimicrobial [21] antibacterial [23] and antitumor [24,13] agents. These facts have led many bioorganometallic chemists to focus on the design of metal chelates with biological activity, which could be administered in biological systems. There is data found in the literature on the antitumor activity of organotin(IV). It is believed that the complexes containing electron donating atoms such as oxygen, nitrogen and sulphur form complexes that often exhibit biological activity, particularly if the bonds are formed by means of intramolecular coordination [9].

The role of hydroxamic acids containing oxygen donor atoms has been scientifically investigated for this reason and results found were encouraging [14-16]. The bonding arrangement of the nitrogen of the hydroxamic moiety has not been discovered in metal complexes generated by simple hydroxamic acids, despite investigations on amino hydroxamates in solution and solid state showing that the nitrogen atom may be turned into a very efficient binding site. Unlike their binary systems of hydroxamic acids or amino hydroxamic acids, just a few examples of their ternary systems have been explored. Mixed ligand complexes are useful models for studying hydroxamic acid reactivity in biological systems (e.g. inhibition of metalloenzymes). The goal of a careful analysis of the solution was to find the coordinating mechanisms.

\section{Applications of Organotin Compounds}

The discovery of many new organotin complexes and new applications has led to a great interest of the scientists in designing and synthesis of organotin complexes for anticancer and biomedical applications. One of these important ligands is hydroxamates which can react with proteins and nucleic acids. Its reactivity with proteins' sulfhydryl groups might explain why it inhibits a variety of enzymes, such as the protease papain, which possesses a single free cysteine residue at the active site and is permanently blocked by DIMBOA (2, 4-dihydroxy-7-methoxy-1,4- benzoxazin-3-one).

Organotin compounds have a wide range of biological activities, and various researchers have recently identified several complexes that are effective as antifouling, antibacterial, and antiviral drugs, therefore their use in antioncogenesis has gotten a lot of interest. Triphenyltin and tributyltin, for example, are commercially marketed as bactericides and fungicides. Figure 1 shows photos of antibacterial organotin compounds demonstrating good biological activity against different types of bacteria [24].

Naturally occurring hydroxamic acids have been isolated from microorganisms, mainly fungi and actinomycetes, yeast, bacteria and green plants, and have also been isolated from corn [25] and algal strains. Actinomycetes are Gram-positive organisms and can be found in a wide range of habitats and are particularly abundant in soil. Actinomycetes are recognized as main producers by contributing two-thirds of the known antibiotics that are produced by microorganisms. The potential use of siderophore analogues as medicinal medicines, particularly for chelation treatment [26], has sparked a lot of interest in their research.

Several research were conducted in order to develop possible antitumour organotin(IV) derivatives of physiologically relevant substrates, and certain organotin complexes with antitumour capabilities in vitro were discovered. Many different organotin(IV) complexes have been created and researched for their antitumor properties. As a result, they may be useful substrates for the production of antitumor-active organotin compounds [27].

Due to their considerable biological activities, a great number of organotin(IV) complexes containing a range of chemical ligands have been synthesized and described in recent years; some of these derivatives have been investigated for in vitro action on various types of tumour cells. They're also used as lubricants, antimicrobial boat paint additives, catalysts, polymers, and organic synthesis, among other things [28]. The organotin compound is commonly of moderate to low toxicity only with few exceptions (trimethyltin and triphenyltin derivative). Some of the most important biological applications are: 

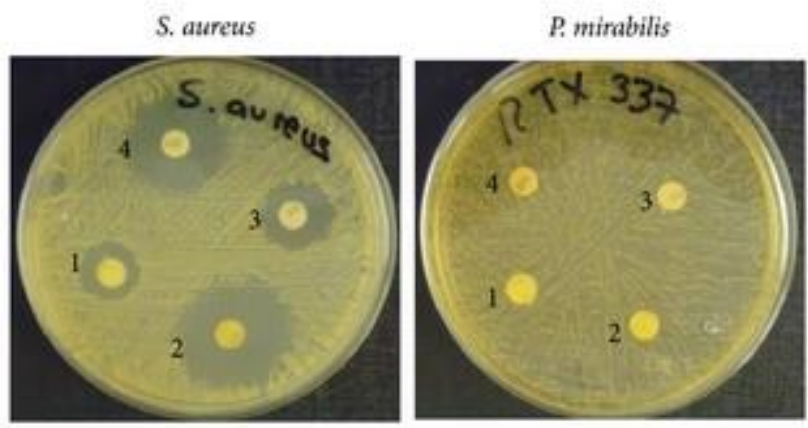

P. aeruginosa

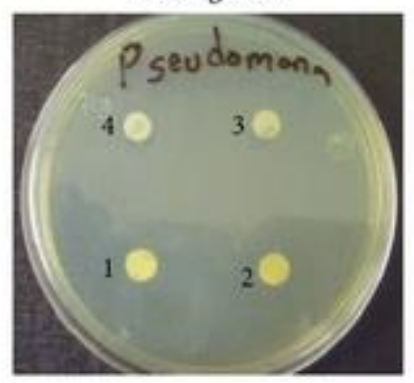

E. coli
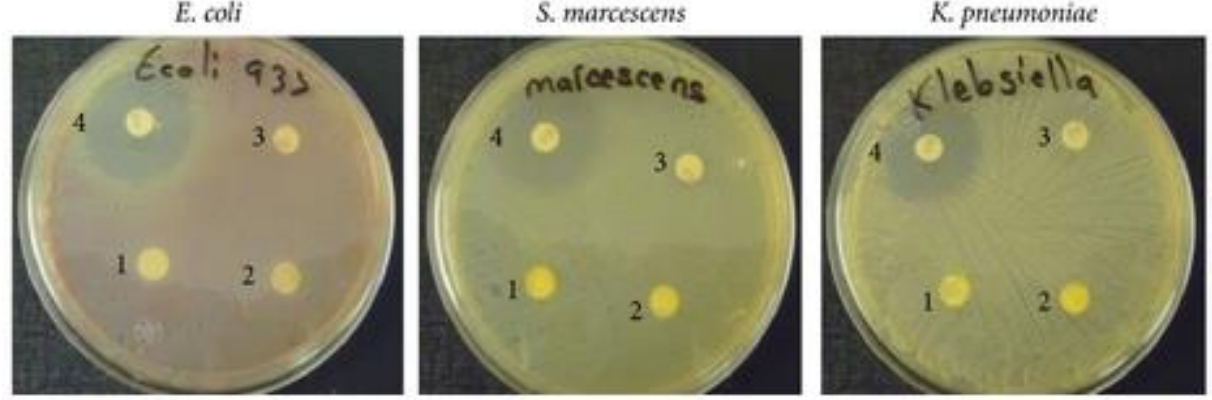

Figure 2. Images of antibacterial organotin compounds [24]

\subsection{Biological Applications \\ Pharmaceutical Applications}

Tin compounds are used to address a number of dental disorders in a variety of methods in dentistry. Tin(II) hexafluoro zirconate polishes teeth and reduces enamel solubility and decay, according to research. In the vulcanizing of silicon rubbers used for protection, di-n-butyltin dilaurate and tin(II) acetate were utilized as catalysts.

Tin, tin oxide, tin(II) chloride, and sodium stagnates were shown to be effective against staphylococcal pathogenicity by Frouin and Gregoire in 1917. However, following research found on staphylococcal activity in rabbits or humans in vitro or in vivo. Despite this, the idea that typical stannous salts are useful in the treatment of cutaneous sepsis has persisted, presumably due to the fact that simple tin compounds exhibit distinct germicidal and bacteriostatic properties.

\section{Cancer Chemotherapy}

Organotin chemicals have a diverse range of biological effects. Several researchers have identified complexes that are effective as antifouling, antibacterial, and antiviral drugs in recent years, therefore their applications for antioncogenesis have gotten a lot of interest. Organotin were the first identified organotin compounds with some cancer activity [29]. Yousif's group recently synthesized a di-organotin (IV) complex with valsartan as a ligand, and this compound demonstrated outstanding inhibitory effectiveness of A549 cells [30].

Another family of organotin chemicals that has been thoroughly investigated and has consistent antiP388 action The common formula for lymphatic leukemia in mice is $\mathrm{R}_{2} \mathrm{SnX}_{2} \mathrm{~L}_{2}$, where $\mathrm{L}$ is frequently a bidentate ligand with oxygen and/or nitrogen donor atoms, as illustrated [31]. Tin(IV) complexes with biologically significant compounds were discovered to have anti-tumour action. The amino acids adenine and glycylglycine, as well as 2-mercapoethanesulphate and purine-6-thiol, are all ligands in these 
complexes. Dihalobis (benzoly-acetonato) tin(IV) was discovered to be effective against the sarcoma 180 tumour in mice.<smiles></smiles>

Figure 3. Chemical structure of valsartan di-organotin (IV) complex [30].

In mice, derivatives of steroids with organotin have been shown to have anti-tumour efficacy, such as triphenyltin cholate, which was tested against transplanted tumour fragments in AKL strain cancer-pron mice. Iminodiacetic acid diorganotin(IV) derivatives are potential antitumor drugs in mice with P399 and L1210 leukemia [31]. In vitro, these compounds were effective against L1210 leukemia, P388 leukemia, and P815 leukemia, as well as B16 melanoma and Lewis lung cancer. Figure 4 displays blue-Hoechst cell fluorescence images taken under transmitted light.

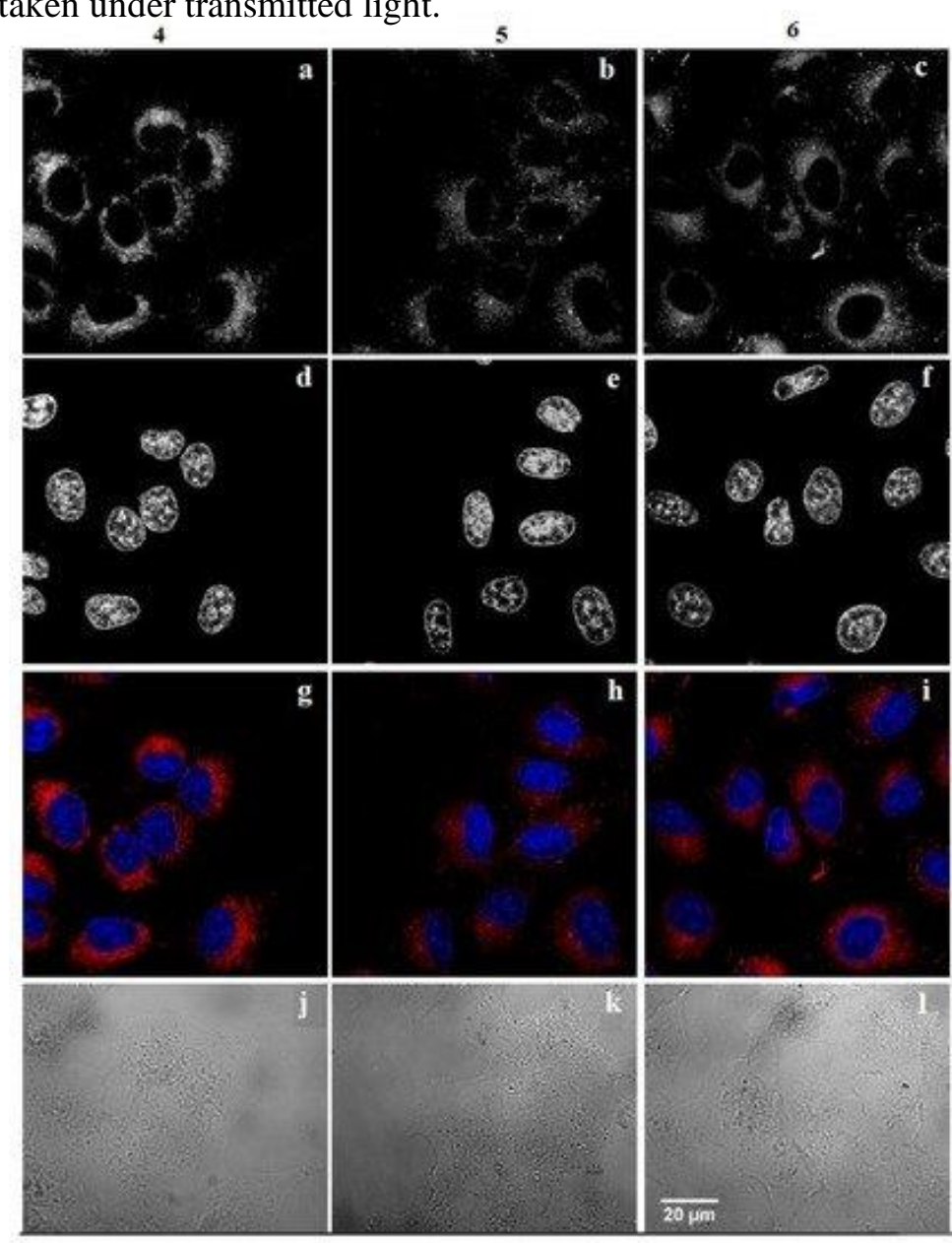

Figure 4. Fluorescent images of blue-Hoechst cell images in transmitted light [31] 


\section{Veterinary Application}

Antihelminthics for poultry, as well as animal husbandry and insecticides for sheep and cattle, have all been used with organotin chemicals. Dibutyltin dilaurate is a component of a commercial drug used to treat worm infestations in chickens, and it has been combined with piperazine and phenothiazine in commercial formulations.

\section{2. Industrial Applications \\ Wood Preservation}

Wood is a wonderful structural material, yet it is prone to biodeterioration, much like other living things. A wide range of organic solvent-based wood preservation formulations contain trialkyltin molecules. Wood may be attacked by many forms of fungus as well as wood-boring insects under extreme conditions. Tributyltin oxide, often known as TBTO, is an organotin chemical that has been used to pretreat wood to protect it from pesticide assaults at concentrations up to $3 \%$ in a solvent like kerosene.

\section{Antifouling Coatings}

Antifouling paints containing tin compounds were utilized to keep aquatic species such salime bacteria, and algae, and sometimes marine animals like hydroids crabs, mollucus, and tunicates from adhering to surfaces. In the early 1960s, triorganotin chemicals were first used as an active component in antifouling paint. With time, frequent ingestion of these substances rises, and tributyltin fluoride develops as a noxious substance. The growth of pacific oysters was found to be harmed by tributyltin compounds in a subsequent investigation [30]. Most nations generally prohibit the use of tributyltin compounds on vessels smaller than 25 meters in length; nonetheless, they are still used on occasion. [30].

\subsection{Agriculture Usage Harvest Defence}

As agrochemicals, a variety of triorganotin compounds have been created and are effectively employed in certain applications. Non-targeted organisms are less harmed by organotin chemicals which have low phytotoxicity and may break down fast in the environment, producing harmless tin residues. Organotin compounds have been banned in agriculture due to their detrimental environmental impacts, and one example of organotin materials to be introduced were organotin (IV) compounds using sulfadiazine as a ligand. Figure 3 depicts the structures of organotin (IV) compound using sulfadiazine as ligand [32].
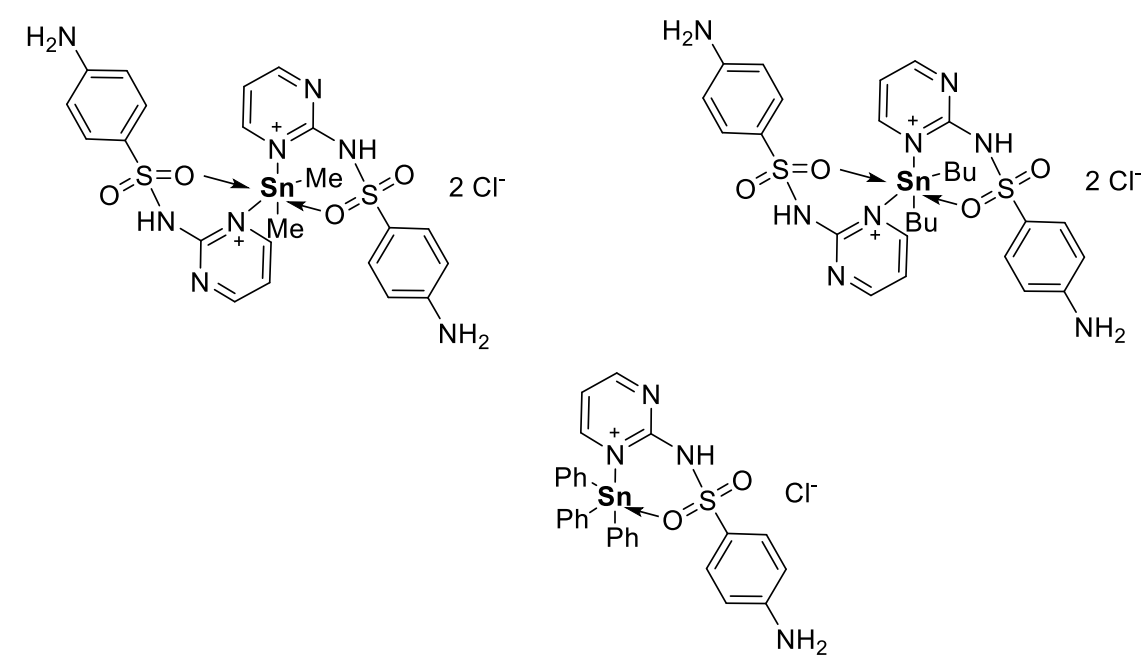

Figure 5. The structure of organotin (IV) compound using sulfadiazine as ligand [32].

\section{Conclusions}

The discovery of many new organotin complexes and new applications has led to a great interest of the scientists in designing and synthesis of organotin complexes for biological, industrial and agriculture biomedical applications. Thus organotin (IV) compounds have showed great biological activity as antimycobacterial anti-fungal and anti-oxidant. Furthermore, they have been used in agriculture as crop protection additives. Organotin (IV) compounds are less damaging to non-targeted organisms since they have a low photo-toxicity and may quickly breakdown in the environment, finally generating harmless tin residues. Lastly, Organotin (IV) compounds give excellent results in industry such as wood preservation, antifouling coating, and plastic photo-stabilizers. 


\section{References}

1. Shaheen F., Ali S. \& Shahzadi S., 2017. Synthesis, Characterization, and Anticancer Activity of Organotin(IV) Complexes with Sodium 3-(1H-Indol-3-yl)propanoate, Russ. J. Gen. Chem., 87, $2937-$ 2943.

2. Ahmed, A. El-Hiti, G. A. Hadi, A. G. Ahmed, D. S. Baashen, M. A. Hashim, H. \& Yousif, E. 2021. Photostabilization of Poly(vinyl chloride) Films Blended with Organotin Complexes of Mefenamic Acid for Outdoor Applications, Appl. Sci. 11, 2853. https://doi.org/10.3390/app11062853

3. Graf,G.G., Arpe,H.J. 1996. Tin, Tin Alloys And Tin Compounds. Ullmann'S Encyclopedia Of Industrial Chemistry, Vol. A27, pp.49-81. . Wilely-VCH, Weinheim.

4. Bufaroosha, M. Salih, N. Hadi, A. G. Ahmed, D. S. Al-mashhadani M. H., Yousif E. 2020. The Effect of UV Aging on the Structure of PVC in the Presence of Organotin(IV) Compounds, ANJS, vol. 23, pp. 57-61.

5. Ali, \& S. Shahzadi, S. 2018. Imtiaz-ud-Din, Anticarcinogenicity and Toxicity of Organotin(IV) Complexes: A Review," Iran J Sci Technol Trans Sci., vol. 42, pp. 505-524.

6. Ullah, H. Previtali, V. Mihigo, H. B. Twamley, B. Rauf, M. K. Javed, F. Waseem, A. Baker, \& R. J. Rozas, I. 2019. Structure-activity relationships of new Organotin(IV) anticancer agents and their cytotoxicity profile on HL-60, MCF-7 and HeLa human cancer cell lines," Eur J Med Chem., vol. 181, pp. 1-10.

7. Maggio,F., Pellerito, A., L,m Grimaudo,S., Mansueto, C.\& Vitturi, R.1994. Organometallic Complexes With Biolgical Molecules II. Synthesis, Solid-State Characterization And In Vivo Cytotoxicity Of Diorganotin(IV) Chloro Derivatives Of Pencillin G. Appl.Organomet.Chem.8: 71-85.

8. Qiu, Y. Zhang, R. Zhang, S. Cheng, S. Li, Q. Ma, C. 2017. Novel organotin(IV) complexes derived from 4-fluorophenyl-selenoacetic acid: synthesis, characterization and in vitro cytostatic activity evaluation," New J Chem., vol. 41, pp. 5639- 5650.

9. Pellerito, L. \& Nagy,L. 2002. Organotin(IV) Complexes Formed With Biologically Active Ligands: Equilibrium And Structural Studies And Some Biological Aspects. Coord. Chem.Rev. 244: 111-150.

10. Alhaydary, E., Yousif, E., Al-Mashhadani, M. H., Ahmed, D. S., Jawad, A. H., Bufaroosha, M., Ahmed, A. A. 2021. Sulfamethoxazole as a ligand to synthesize di- and tri-alkyltin(IV) complexes and using as excellent photo-stabilizers for PVC, Journal of Polymer Research. 28:469.

11. Wong, C.Y.\& Woollins, J.D. 1994. Bidentate Oxygen Donor Chelates Of Silicon Germanium And Tin .Coord.Chem.Rev. 130: 175-241.

12. Duan. J.J.W., Chen. L., Wasserman, Z.R., Lu, Z., Liu,R., Covington, M.b., Qian, M., Hardman, k.D., Mayolda, R.L., Newton, R.C., Christ, d.d.. Wexler, R. R. \& Decicco, C. p. 2002. Discovery Of y lactam Hydroxamic Acids As Selective Inhibitors Of Tumor Necrosis Factor A Converting Enzyme: Designs and Structure- Activity Relationships. J. Med. Chem. 45: 4954-4957.

13. Saxena, A.K.\& Huber, F. 1989. Organotin Compounds And Cancer Chemotherapy. Coord .Chem.Rev. 95: 109-123.

14. Chun-Ying, W., Pin, Y., Lian-Hong, W.\& Li W.2002. Synthesis, Characterization And In Vitro Antitumor Activity Of The Di-N-Butyltin(IV) Complexes Of Some Arylhydroxamtes. Cineses J.Chem.20:453-461.

15. Mohammed, S.A. Najim, L.H. Al-mashhadani, M.H. Ismael, M. Hamad, B.A. Noaman, R. Ibraheem, H. Ahmed, D.S. \& Yousif, E. 2020. Morphological and Photodecomposition Rate Constant Study of PVC Films Doped with Sulfadiazine Tin (IV) Complexes, Science Letters, vol. 14, pp. 88-96.

16. Gielen, M., Dalil, H., De Vos, D., Biesemans, M \& Willem,R. 1998. Synthesis Characterization And Anti-Tumour Activity Of Di-Butyltin Salicyloxamte. Metal-Based Drugs 5: 265-266.

17. Devi, J. \& Yadav, J. 2018. Recent Advancements in Organotin(IV) Complexes as Potential Anticancer Agents, Anticancer Agents Med Chem, vol. 18, pp. 335-353.

18. Singh, R.V., Joshi, S.C., Gajraj,A.\& Nagpad,P. 2002. Studies Of Biologically Potent Organotin(IV) And Organosilicon (IV) Complexes Of A Sulfur Donor Ligand Derived From 1- Acetylferrocene. Appl. Organomet.Chem. 16: 713-720.

19. Kucklick, J. R. \& Ellisor, M. D. 2019. A review of organotin contamination in arctic and subarctic regions, Emerg Contam, 5150-5156.

20. Arakwa Y.1998 In: Smith P.J.Ed. Chemistry of Tin. LONDON. Blackie, Academic and Professional, p.338.

21. Kamaludin, N. F. Awang, N. \& Baba, I. Synthesis, 2013. Characterization and Crystal Structure of Organotin(IV) N-Butyl-N-Phenyldithiocarbamate Compounds and their Cytotoxicity in Human Leukemia Cell Lines, PJBS, vol. 16, pp. 12-21. 
22. Kidwai,M., Dave,B., Misra, P., Saxena,R.K.\& Sigh,M. 2000. Novel Synthetic Approach For Antifungal And Antibacterial Organotin Compounds.Inorg.Chem.Commun. 3: 465-468.

23. Ariadna G-O., Carlos C-C., Teresita S-E., Irma R-O., Luis Raúl G-L., Atilano G. C., \& Marco A. V. R. 2013 Novel Organotin(IV) Schiff Base Complexes with Histidine Derivatives: Synthesis, Characterization, and Biological Activity, Hindawi Publishing Corporation Bioinorganic Chemistry and Applications. Volume 2013, 502713, 12 pages http://dx.doi.org/10.1155/2013/502713.

24. Dabed, R.G., Tora, M.I., Corcuera,L.J.\& Niemeyer,H.M. 1983. Complexes Of Bivalent Cation with A Hydroxamic Acid from Maize Extracts. Polyhydron 2:106-108.

25. Alberecht-Gary, A.M \& Crumbliss A.L.1999. In Sigel, H.Eds. Metal Ions in Biological System. V.35.Marcel, Dekker. New York.ch7.

26. Khalaf, M. Fadhil, Z. Al-Mashhadani, M. H. Abdallh, M. Bufaroosha, M. Majeed, A. Salih, N. \& Yousif, E. 2020. PVC Films Performance Stabilized by Dibutyltin (IV) Complex for Sustainable Environment. Journal of Physics: Conference Series, pp. 1664.

27. Adeyemi, Jerry O., Gbemisola M. Saibu, Lukman O. Olasunkanmi, Adewale O. Fadaka, Mervin Meyer, Nicole RS Sibuyi, Damian C. Onwudiwe, and Adebola O. Oyedeji. "Synthesis, computational and biological studies of alkyltin (IV) N-methyl-N-hydroxyethyl dithiocarbamate complexes." Heliyon 7, no. 8 (2021): e07693.

28. Kucklick, J. R., \& Ellisor, M. D. 2019. A review of organotin contamination in arctic and subarctic regions. Emerging Contaminants, 5, 150-156.

29. Tikhonov, S. Ostroverkhov, P. Suvorov, N. Mironov, A. Efimova, Y. Plutinskaya, A. Pankratov, A. Ignatova, A. Feofanov, A. Diachkova, E. Vasil'ev Y. \& Grin M. 2021. Tin Carboxylate Complexes of Natural Bacteriochlorin for Combined Photodynamic and Chemotherapy of Cancer è, Int. J. Mol. Sci. 22, 13563. https://doi.org/10.3390/ijms222413563

30. Mohammed, A. Makia, R. Ali, M. Raheem, R. Yousif, E. 2021. Cytotoxic Effects of Valsartan Organotin(IV) Complexes on Human Lung Cancer Cells, Biointerface Research in Applied Chemistry. $11,1,8156-8164$.

31. Olushola Sunday, A., Abdullahi Alafara, B., \& Godwin Oladele, O. 2012. Toxicity and speciation analysis of organotin compounds. Chemical Speciation \& Bioavailability, 24(4), 216-226.

32. Ahmed, A. Abdallh, M. Al-Mashhadani, M. H. Ahmed, D. S. Bufaroosha, M. Jawad, A. H. Yousif, E. 2021. Environmental Stability of Poly(Vinyl Chloride) Modified by Schiff's Base under Exposure to UV, Biointerface Research in Applied Chemistry, vol. 11, pp. 13465 - 13473. 